\title{
The estimation of blood galactose using a glucose oxidase-catalase reagent
}

\author{
C. H. BOWDEN
}

From the R.A.F. Institute of Pathology and Tropical Medicine, Halton, Aylesbury, Bucks

SYNOPSIS The removal of the blood glucose by yeast fermentation in a conventional blood galactose $\frac{\vec{\Omega}}{0}$ method is replaced by an enzymic reaction using a glucose oxidase-catalase reagent. The method $\frac{0}{\sigma}$ can be readily modified to suit a variety of blood sugar estimation methods.

Blood galactose is usually estimated by a standard blood sugar method (Maclagan, 1940; King and Wootton, 1956; Dische, Stamm, and Goudie, 1958) after the removal of glucose by yeast fermentation. Up to June 1959 the local supplies of yeast gave satisfactory results. However, from June 1959 galactose-fermenting strains of yeast appeared to increase. Periodic investigation up to January 1961 of batches of yeast obtained from various sources showed fermentation of $100 \mathrm{mg}$. $/ 100 \mathrm{ml}$. galactose standards ranging from 10 to $85 \%$ during the incubation period of 15 minutes.

Although it proved possible to produce under laboratory conditions $10 \mathrm{~g}$. of a non-galactose fermenting yeast (Saccharomycodes ludwigii) in three days, it was not a practical proposition for routine use on infrequent tests, especially as it proved difficult to store in a fully active state.

An attempt was made to estimate galactose by estimation of blood glucose using a glucose oxidase method (Huggett and Nixon, 1957) and total sugars by the Folin and Wu method (Dische, 1955) then taking the differences as representing the blood galactose. This proved to be time consuming and necessitated an excessive number of capillary blood samples from the patient; also it was no more specific for galactose than the fermentation method.

The estimation of glucose using glucose oxidase (Huggett and Nixon, 1957; Middleton and Griffiths, 1957) involves the use of peroxidase and an oxygen acceptor to remove the hydrogen peroxide formed.

$$
\text { Glucose }+\mathrm{O}_{2}+\mathrm{H}_{2} \mathrm{O} \underset{\text { glucose oxidase }}{\longrightarrow} \text { gluconic }
$$$$
\text { acid }+\mathrm{H}_{2} \mathrm{O}_{2}
$$$$
\mathrm{H}_{2} \mathrm{O}_{2}+\text { chromogenic acceptor } \longrightarrow \mathrm{H}_{2} \mathrm{O}+
$$

coloured oxidation product

$$
\text { peroxidase }
$$

Received for publication 17 January 1963.
However, by replacing peroxidase with catalase, the hydrogen peroxide can be removed and the $s$ oxidation allowed to proceed without an oxygen acceptor. Thus, yeast fermentation can be successfully replaced by a combined glucose oxidasecatalase reagent.

$$
2 \mathrm{H}_{2} \mathrm{O}_{2} \underset{\text { catalase }}{\longrightarrow} \mathrm{O}_{2}+2 \mathrm{H}_{2} \mathrm{O}
$$

REAGENTS

1 SODIUM SULPHATE-SODIUM TUNGSTATE SOLUTION Mix $920 \mathrm{ml} .3 \%$ sodium sulphate $\left(\mathrm{Na}_{2} \mathrm{SO}_{4} \cdot 10 \mathrm{H}_{2} \mathrm{O}\right)$ with $\stackrel{2}{2}$ $80 \mathrm{ml} .10 \%$ sodium tungstate $\left(\mathrm{Na}_{2} \mathrm{WO}_{4} \cdot 2 \mathrm{H}_{2} \mathrm{O}\right)$.

\section{$27 \%$ COPPER SULPHATE SOLUTION}

3 GALACTOSE AND GLUCOSE STANDARDS Galactose or glucose, $1.1429 \mathrm{~g}$., is dissolved in $1,000 \mathrm{ml}$. of saturated benzoic acid. This is the stock solution.

A ' $100 \mathrm{mg} . / 100 \mathrm{ml}$. blood' working standard is freshly prepared by diluting $5 \mathrm{ml}$. of the stock solution to $100 \mathrm{ml}$. ₹ with sodium sulphate-sodium tungstate solution, i.e., 0 equivalent to $0.2 \mathrm{ml}$. blood at $100 \mathrm{mg}$. $/ 100 \mathrm{ml}$. concentration taken through the full method to final colorimetric $\frac{D}{0}$ estimation. Standards of other values are made by appropriate dilutions.

4 FOLIN AND WU COPPER AND PHOSPHOMOLYBDATE REAGENTS These are prepared as in the blood glucose method of Dische (1955).

5 GLuCOSE OXIDASE-Catalase REAGent Dissolve $0.5 \mathrm{~g}$. glucose oxidase (1,500 units/g. activity) crude preparation 0 and $0.1 \mathrm{ml}$. catalase (Boehringer activity 3,000 units $/ \mathrm{mg}$.) in $100 \mathrm{ml}$. of $3 \%$ sodium sulphate. It is more economical to make up $1 / 10$ or 1 quantities which are sufficient for a single galactose tolerance test. 


\section{METHOD}

1 For a galactose tolerance test set up samples as follows:

\begin{tabular}{lll} 
Test Blank & Standards \\
\cline { 2 - 3 } & $100 \mathrm{mg} . /$ & $50 \mathrm{mg} . /$
\end{tabular}

Sodium sulphate-sodium

$100 \mathrm{mg} . / 100 \mathrm{ml}$. standard

$100 \mathrm{mg} . / 100 \mathrm{ml}$. standard

Fasting blood

Test specimen

$\begin{array}{llll}3.5 \mathrm{ml} . & 3.5 \mathrm{ml} . & & \\ & & 3.5 \mathrm{ml} . & \\ & & & \\ & & & \\ & & \\ & & \\ & & \mathrm{ml} .5 \mathrm{ml} .\end{array}$

The $p \mathrm{H}$ of the above solutions varies between $\mathbf{7 \cdot 3}$ and $7 \cdot 45$.

2 Add $1 \mathrm{ml}$. glucose oxidase-catalase reagent, mix, and incubate at $37^{\circ} \mathrm{C}$. for 60 minutes.

3 Add $0.3 \mathrm{ml}$. of $7 \%$ copper sulphate solution to precipitate the proteins and centrifuge.

4 Pipette $2 \mathrm{ml}$. samples of the clear filtrate into Folin and $\mathrm{Wu}$ tubes and proceed to the colorimetric estimation as described by Dische (1955) for blood glucose.

\section{USE OF GLUCOSE \\ OXIDASE-CATALASE REAGENT}

Initial investigations using glucose oxidase were confused by two factors. First, crude glucose oxidase contains variable amounts of catalase. One batch gave satisfactory results with or without added catalase, thus making it appear that the glucose oxidaseperoxidase reagent used for glucose estimation (Huggett and Nixon, 1957) was a satisfactory substitute for yeast. However, later batches of glucose oxidase showed that catalase was necessary to prevent product inhibition.

Table I shows the results obtained using three different batches of glucose oxidase with two batches

TABLE I

VARIABILITY OF CATALASE CONTENT IN BATCHES OF GLUCOSE OXIDASE

\begin{tabular}{|c|c|}
\hline & $\begin{array}{l}\text { Percentage of } \\
200 \text { mg./100 ml. } \\
\text { Glucose Standard } \\
\text { Recovery }\end{array}$ \\
\hline $\begin{array}{l}\text { Glucose oxidase batch I }(250 \mathrm{mg} . / 100 \mathrm{ml} .) \text { only } \\
+ \text { catalase batch A } \\
(0.2 \mathrm{ml} . / 100 \mathrm{ml} .) \\
+ \text { catalase batch B } \\
(0.2 \mathrm{ml} . / 100 \mathrm{ml} .) \\
+ \text { peroxidase } \\
(2 \mathrm{ml} . / 100 \mathrm{ml} .)\end{array}$ & $\begin{array}{r}97 \\
58 \\
53 \\
100\end{array}$ \\
\hline $\begin{array}{c}\text { Glucose oxidase batch II }(250 \mathrm{mg} . / 100 \mathrm{ml} .) \text { only } \\
+ \text { catalase batch } \mathrm{A} \\
(0.2 \mathrm{ml} . / 100 \mathrm{ml} .)\end{array}$ & $\begin{array}{l}95 \\
44\end{array}$ \\
\hline $\begin{array}{r}\text { Glucose oxidase batch III }(250 \mathrm{mg} . / 100 \mathrm{ml} .) \\
+ \text { catalase batch } \mathrm{A} \\
(0.2 \mathrm{ml} . / 100 \mathrm{ml} .)\end{array}$ & $\begin{array}{l}40 \\
34\end{array}$ \\
\hline
\end{tabular}

of catalase. The concentration of glucose oxidase was reduced to ensure that a measurable amount of glucose was left from a $200 \mathrm{mg} . / 100 \mathrm{ml}$. standard after 60 minutes' incubation at $37^{\circ} \mathrm{C}$.

The second factor which caused difficulty was that although the protein precipitation with $7 \%$ copper sulphate solution appeared to be complete and clear filtrates were obtained, it was found that enzyme activity was not stopped. Thus, false results on the effectiveness of enzyme concentrations were obtained.

Figure 1 shows the results obtained when $100 \mathrm{mg}$. and $200 \mathrm{mg}$. glucose $/ 100 \mathrm{ml}$. standards were incubated with glucose oxidase-catalase reagent. The enzyme mixture was added to duplicate tubes at intervals of 10 minutes up to 60 minutes. The $7 \%$ copper sulphate solution was added to all tubes at $60 \mathrm{~min}$. and after about two hours the colorimetric estimation was completed. It can be seen that the $100 \mathrm{mg}$. glucose/ $100 \mathrm{ml}$. standard appears to be completely metabolized after 35 to 40 minutes' incubation and that only $7 \mathrm{mg}$. glucose $/ 100 \mathrm{ml}$. appears to be left from the $200 \mathrm{mg}$. glucose $/ 100 \mathrm{ml}$. standard after 60 minutes' incubation. Note that the zero time incubation tubes give reduced readings compared with the standards which did not have enzyme mixture added, showing

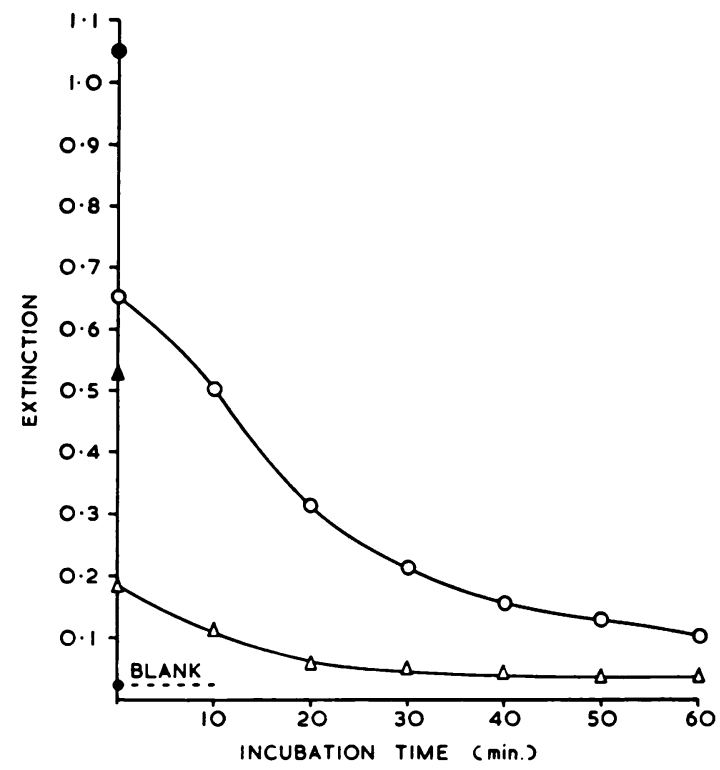

FIG. 1. $\Delta 100 \mathrm{mg}$. glucose $/ 100 \mathrm{ml}$. standard after incubation with glucose oxidase-catalase reagent.

- $100 \mathrm{mg}$. glucose $100 \mathrm{ml}$. standard with enzyme reagent replaced with $3 \%$ sodium sulphate.

$\bigcirc 200 \mathrm{mg}$. glucose $1100 \mathrm{ml}$. standard after enzyme incubation.

- $200 \mathrm{mg}$. glucose $/ 100 \mathrm{ml}$. standard without enzyme incubation. 


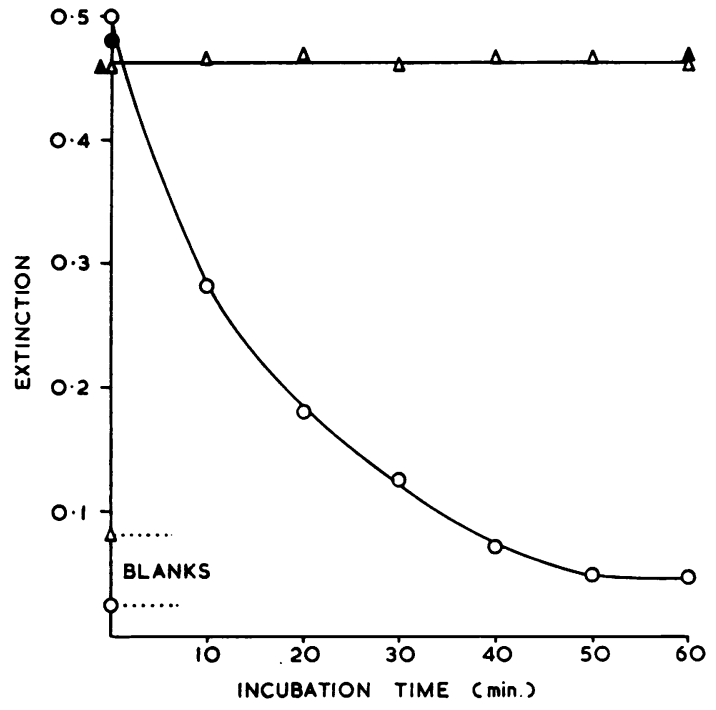

FIG. 2. $\bigcirc 100 \mathrm{mg}$. glucose $1100 \mathrm{ml}$. standard after incubation with glucose oxidase-catalase reagent. The enzyme reaction stopped by heating to $100^{\circ} \mathrm{C}$. for five minutes.

- $100 \mathrm{mg}$. glucose $/ 100 \mathrm{ml}$. standard without enzyme reaction.

$\Delta \quad 100 \mathrm{mg}$. galactose $100 \mathrm{ml}$. standard after enzyme incubation. Enzyme reaction stopped by heating to $100^{\circ} \mathrm{C}$. for five minutes.

- $100 \mathrm{mg}$. galactose $100 \mathrm{ml}$. standard after enzyme incubation without heating to stop enzyme reaction.

that enzyme activity continued after protein precipitation.

Figure 2 shows the results of a similar experiment in which $100 \mathrm{mg}$. $/ 100 \mathrm{ml}$. glucose and galactose standards were incubated with glucose oxidase-catalase reagent and the enzymic reaction stopped by heating the tubes to $100^{\circ} \mathrm{C}$ for five minutes. The tubes were cooled and the proteins precipitated by the addition of $7 \%$ copper sulphate solution. After 60 minutes' incubation only $4 \mathrm{mg}$. $/ 100 \mathrm{ml}$. of glucose was left. No loss of galactose was observed with or without subsequent activation by heat.

\section{DISCUSSION}

In the routine method it is desirable to ensure the maximum removal of glucose, therefore it is neither necessary nor desirable to carry out heat inactiva- $\overparen{D}$ tion. The above experiments indicate that a satisfactory removal of normal levels of blood glucose is attained by an incubation period of 60 minutes.

The replacement of yeast fermentation by a standardized glucose oxidase-catalase enzyme sys- 을 tem is an advantageous procedure but care should be taken to ascertain the activity of the enzyme prepara- $c$ tions. Although some glucose oxidase preparations contain sufficient catalase to enable their use alone to remove glucose, this cannot be relied upon.

I wish to thank the Director General of Medical Services for his permission to publish this paper and Air Commodore W. P. Stamm for his encouragement and interest in this work.

Thanks are also due to Ames Company for gifts of glucose oxidase and the Brewing Industry Research Foundation for cultures of Saccharomycodes ludwigii.

\section{REFERENCES}

Dische, S. (1955). J. clin. Path., 8, 253.

, Stamm, W. P., and Goudie, R. B. (1958). Ibid., 11, 350.

Huggett, A. S., and Nixon, D. A. (1957). Lancet, 2, 368.

King, E. J., and Wootton, I. D. P. (1956). Micro-Analysis in Medical Biochemistry 3rd. ed. Churchill, London.

Maclagan, N. F. (1940). Ouart. J. Med., 9, 151.

Middletan, J. E., and Griffiths, W. J. (1957). Brit. med. J., 2, 1525. 